\title{
PENINGKATAN KETERAMPILAN PEMBELAJARAN MICRO TEACHING BERBASIS VIDUK (VIDEO UNJUK KERJA) PADA MAHASISWA PENDIDIKAN TEKNIK SIPIL DAN PERENCANAAN, FT, UNY
}

\author{
Galeh Nur Indriatno Putra Pratama ${ }^{1}$, Nur Hidayat ${ }^{2}$, Indah Wahyuni ${ }^{3}$ \\ 1,2,3 Pendidikan Teknik Sipil dan Perencanaan, FT, UNY \\ Email: galeh@uny.ac.id
}

\begin{abstract}
ABSTRAK
Tujuan kajian ini adalah untuk mengungkap bagaimana pengaruh implementasi penggunaan media VidUK (Video Unjuk Kerja) dalam pembelajaran micro teaching aspek tinjauan mata pelajaran praktik mampu meningkatkan keterampilan mengajar mahasiswa jurusan Pendidikan Teknik Sipil dan Perencanaan, FT, UNY. Kajian ini merupakan kajian tindakan kelas (classroom research). Populasi kajian ini adalah mahasiswa jurusan Pendidikan Teknik Sipil dan Perencanaan FT UNY yang sedang melaksanakan praktik pengajaran Mikro pada tahun 2018. Sampel kajian adalah kelas B2 sejumlah 11 mahasiswa. Kajian dilaksanakan selama tiga siklus. Tinjauan pertama adalah kemampuan membuka pelajaran, tinjauan kedua adalah penyampaian materi, tinjauan ketiga adalah evaluasi. Observasi kegiatan dilakukan oleh peneliti dengan lembar pengamatan. Penilaian keterampilan juga menggunakan lembar penilaian keterampilan. Data dianalisis secara deskriptif kuantitatif dan kualitatif. Hasil kajian menunjukan bahwa penggunaan media VidUK (Video Unjuk Kerja) dalam pembelajaran micro teaching aspek tinjauan mata pelajaran praktik mampu meningkatkan keterampilan mengajar mahasiswa jurusan Pendidikan Teknik Sipil dan Perencanaan untuk aspek tinjauan kemampuan membuka pelajaran, kemampuan penyampaian materi, serta kemampuan evaluasi; penggunaan media VidUK (Video Unjuk Kerja) dalam pembelajaran micro teaching dapat dijadikan sebagai sarana demonstrasi awal guru kepada siswa sebelum demonstrasi inti dilaksanakan.
\end{abstract}

Kata kunci: keterampilan, pembelajaran micro teaching, VIDUK

\begin{abstract}
This study aims to reveal how the effect of the implementation of the use of VidUK (Video Unjuk Kerja) media in learning micro teaching aspects of the review of practical subjects can improve teaching skills of students majoring in Civil Engineering Education and Planning, FT, UNY. This study is a classroom action study (classroom research). The study population was students majoring in Civil Engineering Education and Planning of FT UNY who were carrying out the practice of teaching Micro in 2018. The study sample was a B2 class of 11 students. The study was carried out for three cycles. The first review is the ability to open lessons, the second review is the delivery of material, the third review is evaluation. Observation of activities carried out by researchers with observation sheets. Skills assessment also uses skills assessment sheets. Data were analyzed descriptively quantitative and qualitative. The results of the study show that the use of VidUK (Video Unjuk Kerja) media in learning micro teaching aspects of practical subjects review can improve teaching skills of students majoring in Civil Engineering Education and Planning for aspects of reviewing the ability to open lessons, the ability to deliver material, and the ability to evaluate; the use of VidUK (Performance of Video) media in micro teaching can be used as a means of teacher's initial demonstration to students before the core demonstration implementated.
\end{abstract}

Keywords: skill, micro teaching learning, VIDUK

\section{PENDAHULUAN}

Micro teaching merupakan salah satu mata kuliah yang wajib ditempuh oleh mahasiswa pendidikan di UNY. Micro teaching bertujuan untuk meningkatkan kemampuan dalam proses pembelajaran atau kemampuan profesional calon guru dan/atau meningkatkan kemampuan tenaga pendidik dalam berbagai keterampilan. Pembelajaran mikro saat ini, khususnya di Fakultas Teknik UNY minim sekali video tutorial pelatihan 
berbasis unjuk kerja terutama sebagai pengantar saat tinjauan mata pelajaran praktik bengkel. Mahasiswa micro teaching di Fakultas Teknik wajib mengambil praktik mengajar pada mata pelajaran teori dan praktik (bengkel). Permasalahan yang muncul saat ini adalah belum adanya rool model pembelajaran mikro yang runtut sesuai dengan kompetensi minimal seorang calon guru yang handal dibidang praktik bengkel. Berdasarkan pengamatan yang dilakukan saat ini, ada beberapa mahasiswa yang kurang terampil saat praktik pembelajaran mikro dan kurang menguasai materi dibidang praktik bengkel. Penguasaan keterampilan calon guru wajib harus dimiliki oleh Mahasiswa FT UNY, hal ini dikarenakan kebutuhan Guru yang kompeten dalam praktik bengkel sangat besar oleh beberapa SMK. Berdasarkan hasil pengamatan yang telah dilakukan, dapat dijelaskan bahwa mahasiswa sering kali kebingungan untuk memulai pelajaran, penyampaian materi serta demonstrasi dibidang praktik bengkel. Hal ini tentu sangat memprihatinkan, dikarenakan salah satu keunggulan dari Fakultas Teknik UNY adalah pembelajaran di bengkel yang berbasis pada unjuk kerja. Permasalahan ini apabila tidak segera diselesaikan akan berdampak pada turunnya kepercayaan user terhadap kualitas mahasiswa Fakultas Teknik dalam pembelajaran di SMK.

Guna menyelesaikan beberapa permasalahan di atas, diperlukan media bantuan saat implementasi pembelajaran micro teaching berbasis pada unjuk kerja. Video unjuk kerja akan menjadi salah satu sumber belajar mahasiswa saat akan tampil micro teaching. Secara umum video unjuk kerja meliputi mata pelajaran teori dan mata pelajaran praktik di bengkel. Komponen video unjuk kerja untuk pembelajaran mikro, terdiri atas: 1) membuka pelajaran, meliputi: penyiapan siswa, penyampaian kompetensi dasar, apersepsi; 2) kegiatan ini, meliputi: penguasaan dan penyampaian materi secara sistematis dan logis; interaksi/skenario pembelajaran dengan mempertimbangkan kesesuaian langkah pembelajaran, keefektifan pengelolaan kelas, ketepatan teknik bertanya, kesesuaian metode dan media pembelajaran dengan kompetensi dasar, kecakapan penggunaan media; penggunaan bahasa serta penampilan meliputi: volume suara, kejelasan vokal, keterampilan berbicara, ketepatan penggunaan isyarat, keluwesan gerak, kepercayaan diri, pandangan mata serta ketepatan alokasi waktu; 3) menutup pelajaran, terdiri atas: evaluasi proses dan hasil pembelajaran, penyimpulan, rancangan materi selanjutnya dan pemberian tugas. Video unjuk kerja mata pelajaran praktik di bengkel secara umum akan menekankan pada demonstrasi, penggunaan alat, prosedur kerja serta implementasi K3. Diharapkan melalui media pembelajaran micro teaching berbasis video unjuk kerja dapat meningkatkan keterampilan mengajar mahasiswa untuk aspek tinjauan kemampuan komunikasi, kemampuan membuka pelajaran, kemampuan penyampaian materi, serta kemampuan evaluasi.

Pembelajaran micro teaching merupakan pelatihan tahap awal dalam pembentukan kompetensi mengajar bagi calon guru (Pratama dan Triyono, 2015). Kompetensi dasar mengajar perlu pengaktualisasian, sehingga calon guru benar-benar mampu menguasai setiap komponen keterampilan dasar mengajar, baik secara terbatas maupun terpadu dalam proses pembelajaran yang disederhanakan (Sukaswanto, 2013). Secara umum, 
pengajaran mikro bertujuan untuk membentuk dan mengembangkan kompetensi dasar mengajar sebagai bekal praktik mengajar (real-teaching) di sekolah/lembaga pendidikan dalam program PLT. Secara khusus, tujuan pengajaran mikro (Tim Penyusun Materi Panduan Pengajaran Mikro, 2018) adalah sebagai berikut: 1) Memahami dasar-dasar pengajaran microteaching; 2) Melatih mahasiswa menyusun Rencana Pelaksanaan Pembelajaran (RPP); 3) Membentuk dan meningkatkan kompetensi dasar mengajar terbatas dan terpadu; 4) Membentuk kompetensi kepribadian; 5) Membentuk kompetensi sosial. Kompetensi dasar mengajar dalam pengajaran mikro adalah kemampuan minimal yang harus dicapai oleh mahasiswa pada pengajaran mikro. Selengkapnya kompetensi dasar dalam pengajaran mikro adalah sebagai berikut: 1) Memahami dasar-dasar pengajaran micro teaching; 2) Menyusun Rencana Pelaksanaan Pembelajaran; 3) Mempraktikkan keterampilan dasar mengajar terbatas; 4) Mempraktikkan keterampilan dasar mengajar terpadu dan 5) Mengevaluasi praktik pengajaran mikro.

Media berasal dari bahasa Latin medius yang secara harfiah berarti 'tengah', 'perantara' atau 'pengantar'. Dalam bahasa arab, media adalah perantara atau pengantar pesan dari pengirim kepada penerima (Arsyad, 2003). Media adalah segala bentuk dan saluran yang digunakan untuk menyampaikan pesan atau informasi. Kata media sering diganti dengan mediator. Fleming (Arsyad, 2003) dapat dijelaskan mediator mencerminkan pengertian setiap sistem pembelajaran yang melakukan peran mediasi, mulai dari guru sampai peralatan canggih dapat disebut media. Schramm dalam buku Sunaryo Soenarto (2014) berpendapat media pembelajaran adalah teknologi pembawa pesan (informasi) yang dapat dimanfaatkan untuk keperluan pembelajaran. Arief S. Sadiman (1986) berpendapat, media pembelajaran adalah segala sesuatu yang dapat digunakan untuk menyalurkan pesan dari pengirim ke penerima, sehingga dapat merangsang pikiran, perasaan, perhatian dan minat mahasiswa sehingga proses belajar terjadi. Pelaksanaan Proses Belajar Mengajar (PBM) dapat dioptimalisasi dengan menggunakan metode pembelajaran dan media pembelajaran saat mengajar. Pemilihan metode pembelajaran dan media pembelajaran yang tepat akan memperlancar PBM. Sebagai mahasiswa calon guru atau pengajar khususnya mengajar materi keteknikan (bidang teknik) sangat perlu memahami ragam media pembelajaran, prosedur perancangan, cara pemakaian, serta cara memelihara media pembelajaran. Maksudnya adalah agar mahasiswa calon guru dapat melaksanakan pembelajaran secara proporsional, efektif, dan efisien.

Proses belajar mengajar pada hakikatnya adalah proses komunikasi, yaitu proses penyampaian pesan dari sumber pesan, melalui saluran atau perantara tertentu, ke penerima pesan. Di dalam proses belajar mengajar pesan tersebut berupa materi ajar yang disampaikan oleh dosen, sedang saluran atau perantara yang digunakan untuk menyampaikan pesan/materi ajar adalah media pembelajaran atau disebut juga sebagai media instruksional. Fungsi media pembelajaran dalam proses belajar mengajar adalah untuk: 1) memperjelas penyajian pesan agar tidak bersifat verbalistis, 2) mengatasi keterbatasan ruang, waktu, dan daya indera, 3) menghilangkan sikap pasif pada subjek belajar, 4) membangkitkan 
motivasi pada subjek belajar. Hamalik (1994) berpendapat, media pembelajaran bermanfaat untuk: 1) meletakkan dasardasar berpikir dan mengurangi verbalisme, 2) memperbesar perhatian siswa, 3) memberikan pengalaman nyata, 4) menumbuhkan permikiran teratur dan kontinyu, dan 5) membantu perkembangan kemampuan bahasa.

Bretz (1971) berpendapat, media dibagi menjadi tiga unsur, yaitu unsur: suara, visual, dan gerak. Media visual sendiri dibedakan menjadi tiga, yaitu: gambar, garis, dan simbol yang merupakan suatu bentuk sehingga dapat ditangkap dengan indera penglihatan. Media yang tidak diproyeksikan menurut pendapat Heinich (1993) meliputi: 1) Realita, yaitu benda nyata yang digunakan sebagai bahan belajar, 2) Model, yaitu benda tiga dimensi yang merupakan representasi dari benda sesungguhnya, 3) Grafis, yaitu gambar atau visual yang penampilannya tidak diproyeksikan, seperti: grafik, chart, poster, dan kartun, serta 4) Display, yaitu medium yang penggunaannya dipasang di tempat tertentu sehingga dapat dilihat informasi dan pengetahuannya.

Media video pembelajaran dapat digolongkan kedalam jenis Media Audio Visual Aids (AVA) atau media yang dapat dilihat atau didengar. Media Audio Motion Visual (media audio visual gerak) yakni media yang mempunyai suara, gerakan dan dapat dilihat. Informasi yang disajikan melalui media ini berbentuk dokumen yang hidup, dapat dilihat dilayar monitor atau ketika diproyeksikan ke layar lebar melalui projector dapat didengar suaranya dan dapat dilihat gerakannya (video atau animasi).

Salah satu media video yang saat ini banyak dipergunakan di dalam pembelajaran adalah screenscast. Screencast adalah rekaman digital dari output layar komputer dan dikenal sebagai screen capture video. Screencast pada dasarnya adalah sebuah film dari perubahan yang terjadi dari waktu ke waktu yang menunjukkan bahwa seorang pengguna melihat pada layar komputer, kemudian diperjelas dengan bantuan narasi audio untuk lebih memperjelas instruksi atau materi pada video tersebut. Munir (2013:2) dapat dijelaskan, screenscast merupakan media guru yang dikembangkan untuk proses pembelajaran, agar mudah dipahami oleh siswa dalam menguasai materi pembelajaran dan sebagai media alternatif yang mampu meningkatkan motivasi belajar siswa. Cheppy Riyana (2007) berpendapat, media video pembelajaran adalah media yang menyajikan audio dan visual yang berisi pesan-pesan pembelajaran baik yang berisi konsep, prinsip, prosedur, teori aplikasi pengetahuan untuk membantu pemahaman terhadap suatu materi pembelajaran. Video merupakan bahan pembelajaran tampak dengar (audio visual) yang dapat digunakan untuk menyampaikan pesan-pesan/materi pelajaran. Dikatakan tampak dengar karena unsur dengar (audio) dan unsur visual/video (tampak) dapat disajikan serentak.

Penyampaian materi melalui media video dalam pembelajaran bukan hanya sekedar menyampaikan materi sesuai dengan kurikulum tetapi dengan media tersebut dapat mempengaruhi minat peserta didik dalam pembelajaran. Selain itu, dalam pelajaran praktik peserta didik akan lebih mudah memahami apa yang dilihatnya dalam video daripada hanya melalui buku atau gambar. Kegiatan seperti ini akan memudahkan peserta didik dan guru dalam proses belajar mengajar. Adapun beberapa unsur penilaian dalam media yaitu: tampilan, suara, kejelasan terkait media yang 
disampaikan, alur dan alokasi waktu, selain itu manfaat media video.

Mengajar mengandung sejumlah keterampilan yang terlibat didalamnya, seperti proses pemberian informasi, pertanyaan, penjelasan, mendengar, mendorong, dan sejumlah kegiatan lainnya (Brown, 1991:5). Keterampilan dasar mengajar (basic teaching skills) adalah kemampuan atau keterampilan khusus terkait dengan materi pembelajaran yang harus dimiliki oleh pengajar agar dapat melaksanakan tugas mengajarnya secara efektif, efisien dan profesional. Seorang pengajar harus mempunyai persiapan mengajar, antara lain: menguasai bahan pembelajaran, mampu memilih strategi, metode dan media, penguasaan kelas yang baik, serta menentukan sistem penilaian yang tepat. Pratama (2019) berpendapat, keterampilan yang harus dikuasi oleh para pengajar profesional, seperti: 1) keterampilan menyusun skenario pembelajaran; 2) keterampilan mengelola kelas; 3) keterampilan membuka dan menutup pembelajaran; 4) keterampilan menjelaskan; 5) keterampilan bertanya; 6) keterampilan memberikan penguatan; 7) keterampilan menggunakan media dan alat; 8) keterampilan mengadakan variasi; 9) keterampilan membimbing diskusi; 10) keterampilan melakukan penilaian. Secara umum keterampilan di atas dapat dikelompokkan menjadi 3 kelompok antara lain: kemampuan membuka pelajaran, kemampuan penyampaian materi, dan kemampuan melakukan evaluasi pembelajaran.

\section{METODE}

Pendekatan yang dilakukan dalam kajian ini penelitian tindakan kelas. Kajian ini berupaya memperbaiki dan meningkatkan aspek tinjauan kemampuan berkomunikasi, kemampuan membuka pelajaran, kemampuan penyampaian materi, dan kemampuan melakukan evaluasi pembelajaran yang menjadi tolak ukur keberhasilan calon guru dalam pembelajaran micro teaching.

Subyek tinjuan dalam kajian ini adalah Mahasiswa S1 jurusan Pendidikan Teknik Sipil dan Perencanaan kelas B2 yang akan melaksanakan Praktik Lapangan Terpadu (PLT) di SMK tahun 2019. Kajian ini dilakukan sesuai dengan langkah-langkah model action research menurut Kurt Lewin yang terdiri atas empat komponen, yaitu: (1) perencanaan (planning), (2) tindakan (acting), (3) pengamatan (observing), dan (4) refleksi (reflecting). Tahapan perencanaan adalah melakukan persiapan yang akan dilaksanakan pada langkah pelaksanaan yang mencakup perencanaan silabus pembelajaran mikro, rencana program perkuliahan, dan lembar observasi. Kegiatan praktik mengajar dipilih untuk mata pelajaran praktik bengkel kayu yang dilaksanakan sebanyak 3 kali. Hasil praktik mengajar sesudah dan sebelum diobservasi untuk diketahui perubahannya.

Disamping observasi kegiatan, mahasiswa pembelajaran micro teaching juga dinilai kompetensi secara kualitatif. Tahap refleksi adalah tahap melakukan diskusi antara tim peneliti dan mahasiswa dalam rangka perbaikan pembelajaran. Data dikumpulkan dengan observasi mengunakan lembar observasi kegiatan dan lembar evaluasi pencapaian aspek tinjaun. Data observasi kegiatan dan data dianalisis secara deskriptif kualitatif dan kuantitatif pada setiap kegiatan pembelajaran micro teaching. 


\section{HASIL DAN PEMBAHASAN}

Kajian ini dimulai pada aspek tinjauan kemampuan membuka pelajaran yaitu apersepsi, penyampaian tujuan pembelajaran dan kelancaran serta kejelasan penyampaian saat pembukaan. Kegiatan ini dimaksudkan untuk mengetahui kemampuan awal mahasiswa. Sebanyak 11 mahasiswa dalam kelas ini seluruhnya tampil latihan dasar mengajar dengan waktu 10 menit setiap mahasiswa. Hasil observasi dalam kegiatan ini menunjukan bahwa penampilan mahasiswa masih banyak mengalami kesulitan dalam berkomunikasi dan tidak semua komponen dalam membuka dan menutup pelajaran ditampilkan, hal ini dikarenakan mahasiswa kesulitan dalam penyampaian apersepsi materi pelajaran praktik bengkel.

Tinjauan pertama dilakukan penggunaan bantuan media VidUK untuk aspek tinjauan kemampuan membuka pelajaran. Mahasiswa dilatih masing-masing selama 10 menit. Materi yang dilatihkan adalah volume suara, menyampaikan apersepsi, kelancaran berbicara, kesesuaian dengan tujuan pembelajaran, kejelasan penyampaian saat pembukaan. Dalam satu tatap muka, semua mahasiswa melakukan latihan ini diulang hingga 3 kali secara langsung dengan menggunakan bantuan media VidUK. Hasil penilaian pada kegiatan ini adalah seperti terlihat pada tabel 1-3 di bawah ini.

Tabel 1. Penilaian Aspek Tinjauan Kemampuan Berkomunikasi (Pertama)

\begin{tabular}{crrrrrrr}
\hline $\begin{array}{c}\text { No Urut } \\
\text { Mahasiswa }\end{array}$ & Suara & Apersepsi & Kelancaran & $\begin{array}{c}\text { Tujuan } \\
\text { Pembelajaran }\end{array}$ & Kejelasan & $\begin{array}{c}\text { Jumlah } \\
\text { Skor }\end{array}$ & $\begin{array}{c}\text { Rerata } \\
\text { Skor }\end{array}$ \\
\hline 1 & 1 & 1 & 1 & 1 & 1 & 5 & 1 \\
2 & 1 & 1 & 1 & 1 & 1 & 5 & 1 \\
3 & 1 & 1 & 1 & 1 & 1 & 5 & 1 \\
4 & 2 & 1 & 1 & 1 & 1 & 6 & 1.2 \\
5 & 2 & 2 & 2 & 1 & 2 & 9 & 1.8 \\
6 & 2 & 2 & 2 & 2 & 2 & 10 & 2 \\
7 & 1 & 1 & 1 & 1 & 1 & 5 & 1 \\
8 & 2 & 2 & 2 & 2 & 2 & 10 & 2 \\
9 & 2 & 2 & 1 & 1 & 1 & 7 & 1.4 \\
10 & 1 & 1 & 1 & 2 & 1 & 6 & 1.2 \\
11 & 1 & 1 & 1 & 1 & 1 & 5 & 1 \\
Jumlah & 16 & 15 & 14 & 14 & 14 & & \\
Rerata Skor & 1.455 & 1.364 & 1.273 & 1.273 & 1.273 & & 1.327 \\
\hline
\end{tabular}

Tabel 2. Penilaian Aspek Tinjauan Kemampuan Berkomunikasi (Kedua)

\begin{tabular}{crrrrrrr}
\hline $\begin{array}{c}\text { No Urut } \\
\text { Mahasiswa }\end{array}$ & Suara & Apersepsi & Kelancaran & $\begin{array}{c}\text { Sujuan } \\
\text { Pembelajaran }\end{array}$ & Kejelasan & $\begin{array}{c}\text { Jumlah } \\
\text { Skor }\end{array}$ & $\begin{array}{c}\text { Rerata } \\
\text { Skor }\end{array}$ \\
\hline 1 & 2 & 2 & 2 & 2 & 2 & 10 & 2 \\
2 & 1 & 2 & 2 & 2 & 2 & 9 & 1.8 \\
3 & 2 & 3 & 2 & 2 & 1 & 10 & 2 \\
4 & 2 & 3 & 2 & 2 & 1 & 10 & 2 \\
5 & 2 & 2 & 3 & 2 & 2 & 11 & 2.2 \\
6 & 2 & 2 & 3 & 2 & 2 & 11 & 2.2 \\
\hline
\end{tabular}


Peningkatan Keterampilan Pembelajaran... (Galeh/ hal. 13-23)

\begin{tabular}{|c|c|c|c|c|c|c|c|}
\hline \multirow[b]{2}{*}{$\begin{array}{l}\text { No Urut } \\
\text { Mahasiswa }\end{array}$} & \multicolumn{5}{|c|}{ Skor Aspek Tinjuan Berkomunikasi } & \multirow[b]{2}{*}{$\begin{array}{l}\text { Jumlah } \\
\text { Skor }\end{array}$} & \multirow[b]{2}{*}{$\begin{array}{l}\text { Rerata } \\
\text { Skor }\end{array}$} \\
\hline & Suara & Apersepsi & Kelancaran & $\begin{array}{c}\text { Tujuan } \\
\text { Pembelajaran } \\
\end{array}$ & Kejelasan & & \\
\hline 7 & 1 & 2 & 2 & 1 & 1 & 7 & 1.4 \\
\hline 8 & 2 & 2 & 2 & 2 & 2 & 10 & 2 \\
\hline 9 & 2 & 3 & 2 & 2 & 1 & 10 & 2 \\
\hline 10 & 1 & 2 & 1 & 1 & 2 & 7 & 1.4 \\
\hline 11 & 2 & 3 & 1 & 2 & 2 & 10 & 2 \\
\hline Jumlah & 19 & 26 & 22 & 20 & 18 & & \\
\hline Rerata Skor & 1.727 & 2.364 & 2.000 & 1.818 & 1.636 & & 1.909 \\
\hline \multicolumn{8}{|c|}{ Tabel 3. Penilaian Aspek Tinjauan Kemampuan Berkomunikasi (Ketiga) } \\
\hline \multirow{2}{*}{$\begin{array}{c}\text { No Urut } \\
\text { Mahasiswa }\end{array}$} & \multicolumn{5}{|c|}{ Skor Aspek Tinjuan Berkomunikasi } & & Rerata \\
\hline & Suara & Apersepsi & Kelancaran & $\begin{array}{c}\text { Tujuan } \\
\text { Pembelajaran }\end{array}$ & Kejelasan & $\begin{array}{l}\text { Jumian } \\
\text { Skor }\end{array}$ & $\begin{array}{l}\text { Kerata } \\
\text { Skor }\end{array}$ \\
\hline 1 & 2 & 4 & 4 & 4 & 4 & 18 & 3.6 \\
\hline 2 & 2 & 2 & 4 & 2 & 4 & 14 & 2.8 \\
\hline 3 & 3 & 4 & 3 & 4 & 4 & 18 & 3.6 \\
\hline 4 & 4 & 4 & 4 & 4 & 3 & 19 & 3.8 \\
\hline 5 & 4 & 2 & 4 & 3 & 4 & 17 & 3.4 \\
\hline 6 & 4 & 4 & 4 & 4 & 4 & 20 & 4 \\
\hline 7 & 3 & 4 & 4 & 4 & 3 & 18 & 3.6 \\
\hline 8 & 4 & 4 & 4 & 4 & 4 & 20 & 4 \\
\hline 9 & 4 & 4 & 4 & 4 & 4 & 20 & 4 \\
\hline 10 & 3 & 2 & 3 & 2 & 4 & 14 & 2.8 \\
\hline 11 & 4 & 4 & 3 & 4 & 4 & 19 & 3.8 \\
\hline Jumlah & 37 & 38 & 41 & 39 & 42 & & \\
\hline Rerata Skor & 3.364 & 3.455 & 3.727 & 3.545 & 3.818 & & 3.582 \\
\hline
\end{tabular}

Berdasarkan dari sajian tabel di atas (perubahan siklus I-III) pada aspek tinjauan kemampuan membuka pelajaran dapat dijelaskan, mahasiswa pengalami peningkatan penguasan kemampuan dengan menggunakan media VidUK. Berdasarkan skor rerata per aspek tinjaun keterampilan terdapat peningkatan yang signifikan pada siklus ke-III, hal ini dikarenakan mahasiswa perlu melakukan pembelajaran berulang dan sesuai dengan pembentukan kompetensi masing-masing. Secara lengkap peningkatan per siklus disajikan dalam grafik berikut. 
Peningkatan Keterampilan Pembelajaran... (Galeh/ hal. 13-23)

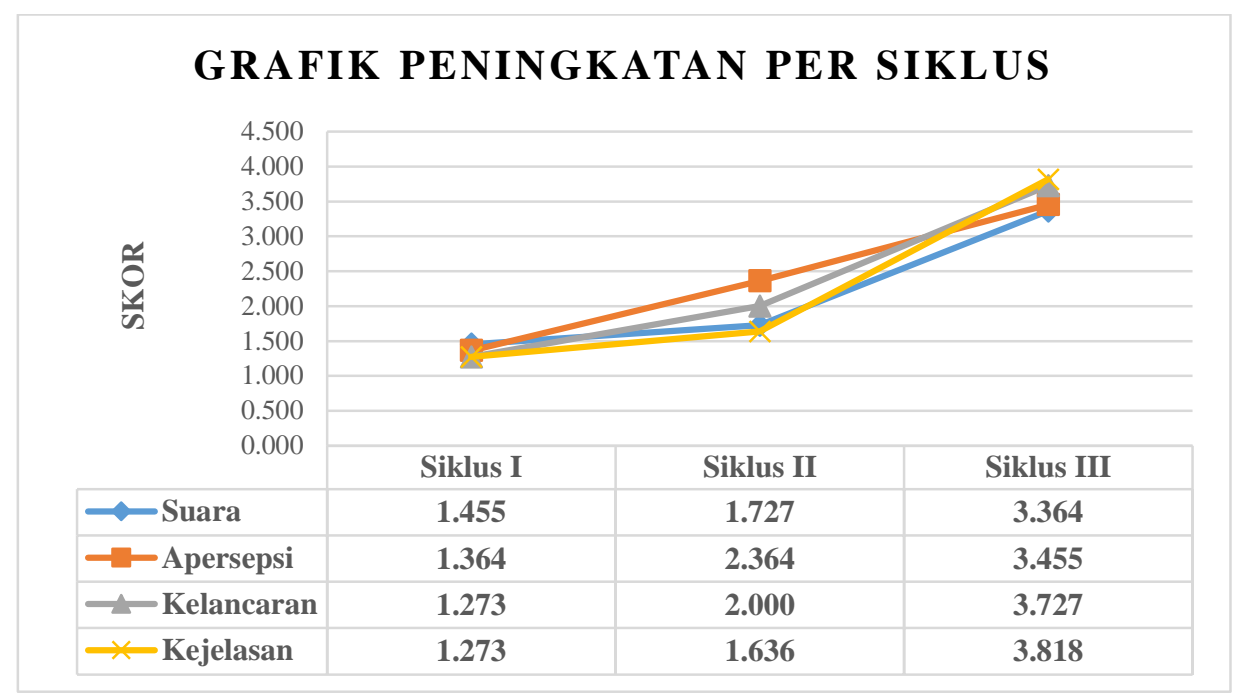

Gambar 1. Grafik Peningkatan untuk Aspek Tinjuan Kemampuan Membuka Pelajaran

Berdasarkan hasil observasi proses dan penilaian di atas, tim kajian melakukan refleksi dan pembahasan tentang langkah apa yang perlu diperbaiki. Hasil refleksi sepakat bahwa mahasiswa memerlukan panduan berupa media pengantar (gambar/video) ketika melakukan penyampaian apersepsi. Pada siklus berikutnya, mahasiswa diminta menyiapkan media pengantar (gambar/video) yang akan disampaikan sesuai dengan tema pembelajaran masing-masing. Hasil refleksi ini digunakan untuk perencanaan latihan berikutnya.

Tinjauan kedua adalah kemampuan penyampaian materi. Pada tinjauan ini mahasiswa awalnya tidak menggunakan bantuan media VidUK, sedangkan selebihnya hingga siklus terakhir menggunakan bantua media VidUK. Materi yang dilatihkan adalah keterampilan mengelola kelas; keterampilan menjelaskan/demonstrasi; keterampilan bertanya; keterampilan memberikan penguatan; keterampilan menggunakan media dan alat peraga. Dalam satu tatap muka, semua mahasiswa melakukan latihan ini diulang hingga 3 kali secara langsung. Hasil peningkatan pada tinjauan kedua ini adalah seperti terlihat pada Gambar 2 di bawah ini. 


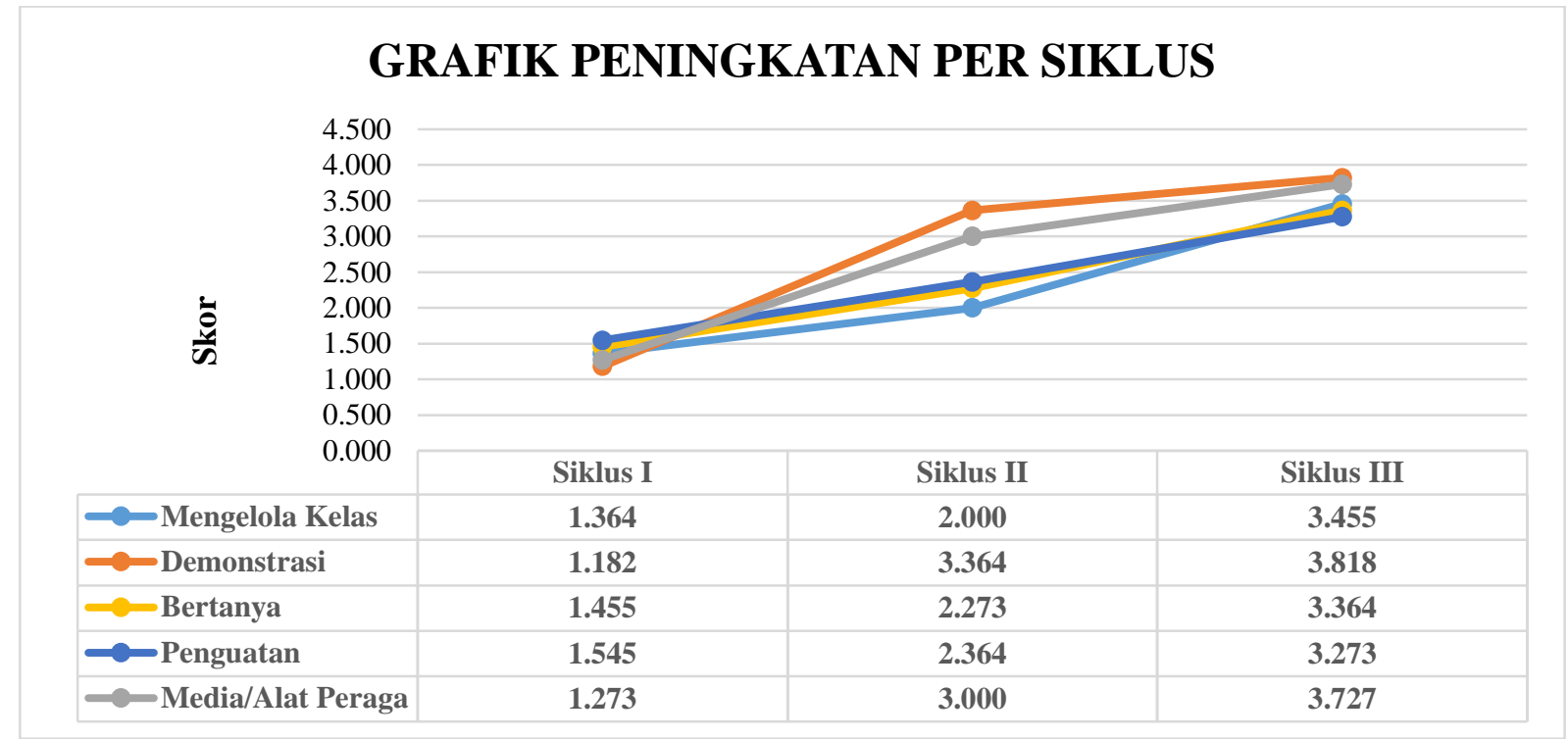

Gambar 2. Grafik Peningkatan untuk Aspek Tinjuan Kemampuan Penyampaian Materi

Hasil observasi kegiatan ini mahasiswa awalnya tidak menggunakan menunjukan bahwa mahasiswa sangat terbantu sekali dengan adanya media VidUK, hal ini dapat dijelaskan melalui media tersebut Guru dapat melihat kuncikunci unjuk kerja sebelum melakukan demontrasi pada mata pelajaran praktik di bengkel. Selain itu, siswa memiliki kecenderung pemahaman terkait materi yang disampaikan oleh Guru yang tinggi, hal ini dapat dijelaskan dari proses praktik yang dituntaskan oleh siswa sesuai dengan jobsheet. bantuan media VidUK, sedangkan selebihnya hingga siklus terakhir menggunakan bantua media VidUK. Materi yang dilatihkan adalah keterampilan membuat simpulan, keterampilan penilaian dan keterampilan pengaitan materi selanjutnya. Mahasiswa melakukan latihan pada tinjauan ketiga ini dengan cara perulangan hingga 3 kali secara langsung. Hasil peningkatan pada tinjauan ketiga ini dapat dilihat pada Gambar 3 di bawah ini.

Tinjauan ketiga adalah kemampuan evaluasi pembelajaran. Pada tinjauan ini

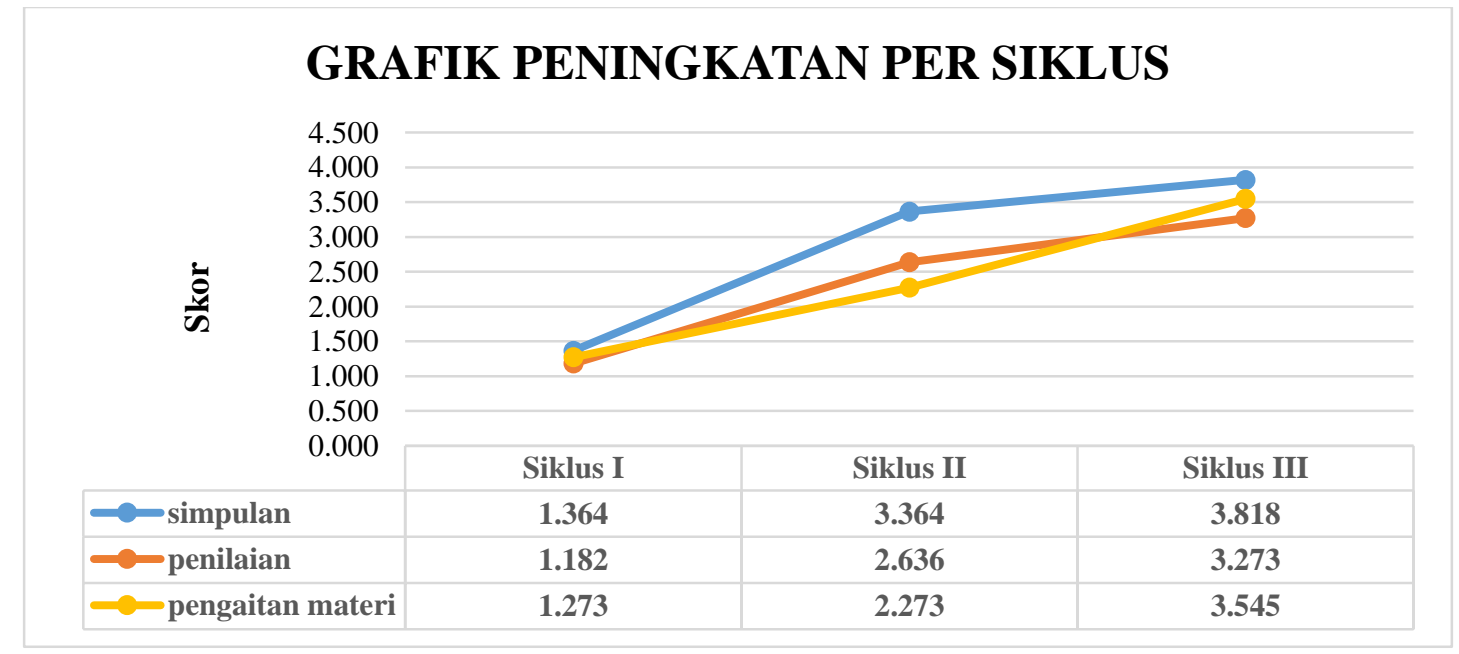

Gambar 3. Grafik Peningkatan untuk Aspek Tinjuan Kemampuan Evaluasi 


\section{SIMPULAN}

Berdasarkan hasil dan pembahasan dalam kajian ini dapat disimpulkan bahwa penggunaan media VidUK (Video Unjuk Kerja) dalam pembelajaran micro teaching aspek tinjauan mata pelajaran praktik (bengkel) mampu meningkatkan keterampilan mengajar mahasiswa jurusan Pendidikan Teknik Sipil dan Perencanaan untuk aspek tinjauan kemampuan membuka

\section{DAFTAR RUJUKAN}

Arief S. Sadiman, dkk. (1986). Seri Pustaka Teknologi Pendidikan No.6 Media Pendidikan.

Arsyad, Azhar. (2003). Media Pembelajaran. Jakarta: PT. Raja Grafindo Persada.

Bretz, Rudy. (1971). A Taxonomy of Communication Media. Education Technology Publication. New Jersey: Englewood Cliffs.

Brown, George (1991). Pengajaran Mikro: Program Keterampilan Mengajar (Terj. Laurens Kaluge). Surabaya: Airlangga.

Cheppy Riyana. (2007). Pedoman Pengembangan Media Video. Jakarta: P3AI UPI.

Hamalik, O. (1994). Media Pendidikan, cetakan ke-7.Bandung: Penerbit PT. Citra Aditya Bakti.

Heinich, R., Molenda, M., \& Russel, J.D. (1993). Instructional Media and the New Technologies of Instruction, $4^{\text {th }}$ ed. New York: Mac. Millan Publishing Company. pelajaran, kemampuan penyampaian materi, serta kemampuan evaluasi. Penggunaan media VidUK (Video Unjuk Kerja) dalam pembelajaran micro teaching dapat dijadikan sebagai sarana demonstrasi awal guru kepada siswa sebelum demonstrasi inti dilaksanakan.

Pratama, G. N. I. P. (2019, May). Basic communication skill drill in microteching context to improve the teching skills of civil engineering and planning education students, faculty of engineering, Yogyakarta State University. In IOP Conference Series: Materials Science and Engineering (Vol. 535, No. 1, p. 012014). IOP Publishing.

Pratama, G. N. I. P., \& Suparman, S. (2019). PENINGKATAN

KETERAMPILAN MENGAJAR MAHASISWA PENDIDIKAN TEKNIK SIPIL DAN PERENCANAAN, FT, UNY MELALUI METODE DRILL BERBASIS KOMUNIKASI VERBAL-NON VERBAL. Jurnal Pendidikan Teknik Sipil, 1(1).

Pratama, G. N. I. P., \& Triyono, M. B. (2015). Peningkatan kualitas pembelajaran prakarya dan kewirausahaan melalui metode CLTSMK. Jurnal Pendidikan Vokasi, 5(3), 313-324.

Sukaswanto. (2013). Mengefektifkan Peran Mahasiswa Peserta Pengajaran Mikro 
Peningkatan Keterampilan Pembelajaran... (Galeh/ hal. 13-23)

dalam Mensupervisi Pelaksanaan

Pengajaran Mikro. JPTK UNY.

Vol.21 No.3.

Sunaryo Soenarto. (2014). Media

Pembelajaran. Yogyakarta: LPPM UNY.

Tim Penyusun Panduan Pengajaran Mikro. (2018). Panduan Pengajaran Mikro. Yogyakarta: LPMPP UNY.

Triyono, B. M., Mohib, N., Kassymova, G. K., Pratama, G. N., Adinda, D., \& Arpentieva, M. R. (2020). The Profile Improvement of Vocational School Teachers' Competencies. Vysshee obrazovanie $v$ Rossii= Higher Education in Russia, 29(2), 151-158.

Wulandari, B., Pratama, G. N. I. P., Hasanah, N., \& Yuniarti, N. (2019, November). Augmented Reality As Android Based Learning Media for Wood Field Laboratory Work. In Journal of Physics: Conference Series (Vol. 1413, No. 1, p. 012035). IOP Publishing. 